\title{
Inter-Clan Conflicts in Somalia: When Peace Happen (Case Study Baidoa District, Bay Region)
}

\author{
Ibrahim Hassan Barrow \\ Lecturer at Faculty of Arts and Social Science \\ Somali International University \\ Mogadishu, Somalia
}

Received: May 12, 2020 Accepted: Aug. 25, 2020 Online published: Sep. 16, 2020

doi:10.5296/ijhrs.v10i4.17702 URL: https://doi.org/10.5296/ijhrs.v10i4.17702

\begin{abstract}
Various clans in Bay region have had conflicts over time onwards with the pastoral communities taking the lead. More specifically, Baidoa district has been registered several inter-clan conflicts within Digil and Mirifle tribe and sub tribes fighting over resources and political issues. This paper examines Inter-Clan Conflicts in Somalia with special reference to Baidoa district community. The study used descriptive research design. The target populations of this study were communities in Baidoa district. The study distributed questionnaire and purposive sampling due to security issue with 103 respondents of male and female who were more familiar with the background of inter-clan conflicts in Baidoa district. The data analyzed with SPSS version of 16.0. The findings show that land ownership dispute, pastures, water, and political power sharing and many other subjects are the major drivers of the inter-clan conflict amongst the communities in Baidoa district. Besides, the results also revealed that lack of rule of law and uncontrollable urbanization including internal displaced people has been frontline frequently rising of inter-clan conflicts due to occupying illegal lands without getting any permission by the land owner/state and many other unmanaged matters are still exist in Baidoa. Currently, the security situation in Baidoa district is quite good but not reliable because of Baidoa outskirts is under control of Al-Shabab militant. Peace is the heart and pillar upon with every life's meaningful progress, security and social harmonize could be reach and continued in each nation's life.
\end{abstract}

Keywords: inter-clan conflict, rule of law, baidoa, peace, security 


\section{Baidoa District Profile}

Baidoa District, locally known as Baydhawo, is a strategic town in south-central Somalia and one of the Bay region districts in Southern regions of Somalia with a population of 370,000 (UNDP, 2005). Currently, Baidoa town is the interim capital of South West State of Somalia. Baidoa is situated approximately 250 kilometers west of Mogadishu and is one of the main Somalia trade corridors, connecting the seaport of Mogadishu and the most resourceful and productive region of Lower Shabelle in Somalia. All roads in and outside of the town were devastated by the civil war that erupted in January 1991 and continuing conflict among the clans in the region has destroyed its infrastructure services while causing huge internal displacement. Currently, the security situation in Baidoa and entire region remains volatile, however, with the large portion of the territory still outside the control of the federal government of Somalia, which really means, it very hard to assess this issue properly. Frequency of inter-clan conflicts are yet remaining the most terrible situation in the city and its outskirt (UNHABITAT, 2017).

The world has been experienced all kinds of conflicts including world wars for both II and I and followed by cold war and other conflicts mainly come from racism, slavery, discrimination, colonialism and many more other associated factors that all driving and inheriting from prolonged conflicts and hostility among society (Kirschner \& Miller, 2019). Conflict is one of the most frequent phenomena over the world and it may come so many ways including resource conflicts, racism, politics and other drivers of inter-clan conflict that yet exists majority of the developing countries particularly sub-Sahara nations (Elmi, 2014). Regarding to historic literature, East Africa nations have often been facing war and domestic conflicts including ethnic conflicts due to weakness of political institutions (Cheeseman etal, 2018).

Somalia has been stateless for nearly three decades because of civil war and other combined negative features including political chaos, conflicts clan-based arm rebels as the ultimate purpose was to overthrow the dictatorship government and finally to influence in the power vacuum and turmoil followed, particularly in the south part (Muse, 2012). Traditionally, Somalia is a clan-based society in which applies certain things in the clan and other clans including disputes among clans is solving through the application of police and judicial system, power sharing, inter-marriage and others including crimes done by the clan individuals (Ayele, 2017).

Southern and Central regions of Somalia has been suffering irregular conflicts among clans through a lot of efforts have been attempted by local people as well as international community to settle the fighting; unfortunately could not happened to achieve to ends the fighting (Ali, etal., 2019).

After the collapse of the central government of Somalia in 1991, the country has shifted into a dangerous situation, and the whole nation was took over by the warlords grouped into clans and sub-clans (Barrow, 2019). Due to created various militias organized in a form of clans were killed and wounded a lot of innocent civilians and as well as so many internal displaced people into neighborhood nations by escaping the endless fire in Somalia particularly when 
the civil war was started in 1991 (Mueller, 2016). As the rule of law does not exist in the country, numerous communities in Southwest regions of Somalia particularly Baidoa district residence and its surrounding remote areas have had conflicts over years with the particular group within the communities taking the lead of all domestic crimes such as land dispute, revenge killings and other bad conflicts (Kusow, 2012).

The study utilized the conflict theory, suggested by Karl Marx, which claims society is in a state of perpetual conflict because of competition for limited resources. It holds that social order is maintaining by domination and power, rather than consensus and conformity. According to conflict theory, those with wealth and power try to hold on to it by any means possible, chiefly by suppressing the poor and powerless.

All efforts related to restructuring peace, stability in Somalia was continued, and taking led by Somalis politicians and it is partners including UN and EU. The fact is Somali clans has made the country to be ungovernable situation and this led to the country being governed 4.5 power sharing formula (Stremlau, 2019).

\section{Research Statement}

Somalia is facing chronic challenge in regard with getting peace and stability due to absence of central government functioning nearly for two decades (Yusuf \& Lewa, 2019). Somalia has been hosting all kinds of conflict, political unrest, warlords, famine, refugees, terrorism, piracy and thousands of continues problems have been seen majority of the Somalia's regions excluding Somaliland (Self-declared Independent State) which is quite peaceful (Healy \& Bradbury, 2010). Abuses by all kinds have been suffering the people of Bay region of Somalia particularly residence in Baidoa district. The most likely example related to domestic crimes are countless such as in June 2019, 13 civilians were killed and 20 injured unlawfully by the state forces during aid distribution and infighting for over land, control of roadblocks in Baidoa district (Human Rights Watch, 2018). During the arresting of Mukhtar Robow (former spokesman and deputy leader of al-Shabab) who was running for the presidential election of South west State of Somalia in 2018 had resulted in the deaths of at least 12 people in Baidoa due to endless protests organized in a form of clan with violent has erupted the whole town. Among those killed was a member of the regional parliament who was from the same tribe (Hassan, 2018).

In responding to these problems related to sub tribe conflicts in Baidoa district, this study was investigating Interclan Conflicts in Baidoa: When Peace Happen. Therefore, the continuation of inter-clan conflicts may encourage very bad consequences including loss of many human lives and other community problems.

The overall objective of the study aims to look particularly the linkages between instability in Southwest regions with special reference to Baidoa district and its negative effects on Southwest administration security situation. The study was guided by the following specific objectives to investigate how high community illiteracy rate promotes inter-clan conflicts in Baidoa district, to examine poor practicing of rule of law can drive inter-clan fighting and final, the study to explore how clan illegal weapons threaten human security in the region 
particularly Baidoa Town.

\section{Related Literature Review}

According Makhubela (2016) study states that clan loyalty is a central priority to all Somali tribes and the political structure of the country has been managed clan system since from the dictatorship administration of Siad Barre. In addition to that $24 \%$ of all violent events were caused by clan conflict over resources including land dispute that have last year's been familiar with the people of Somali. Still Somalia is one of the most dangerous nations in Africa in terms of infighting and human rights violations creating by both Al-Shabaab and government forces due to stateless nearly two decades. From in 2012, Somalia is quite making progress in security, peace and other reforms that all are potential to the country. According to the International Training Programme for Conflict Management (2013) conducted a study on Clan and State Politics with the objectives Interclan reconciliations, conflict resolution-mediations and institutional building in Somalia. The findings of the study were to show that the violence raging between clans in Somalia is one of the most disturbing being getting a peaceful environment. Laura Hammond (2013) his study on Somalia rising: things are starting to change for the world is longest failed particularly investigates some of the challenges facing the new Somali National Government in Mogadishu, following the conclusion of the Transitional Federal Charter and the resulting surprises in the emergence of the post-Transitional leadership. The study found that still Somalia remains politically unstable, plagued by corruption and irregular conflicts among Somalia clans particularly south and central regions. People are still willing peace and stability the whole country including unity of Somaliland which makes self-independent state.

The conflict of Somalia is pretty difficulty to understand as it comes from various ways but mainly it was created from clannism and clan cleavages are one of the sources of Somalia conflict. This prolonged and irregular conflict in Somalia has initiated to divide Somalis, fuel endemic clashes that have been over decades for resources and political power sharing. This simple resulted to marginalized youths in a way of the militia with their respective clans and very difficult to promote dialogue and reconciliation among conflicted clans (Adam, H.2007). General speaking, Somalis are homogenous society as they speak with same language and belongs to the same ethnic group and as well as same religion (Islam). However, clannism is the biggest problem that blocked to every meaning development in the country. Due to more given priority of every Somalis clan, there is no hope in sight to the country's political stability (Makinda, S.2007).

Somalia daily is registering several domestic crimes that damages to the society and the majority drivers of the problems are caused by political disputes, clashes over natural resources, and regional and cross-border hostilities, the profusion of illicit firearms enables high levels of violence to continue years (Inginiir, H.M., 2018).

\section{Security Situation in Baidoa District: Past and Present}

After collapse of central government of Somalia early in the 1990s, Baidoa was one of the most places in Somalia hard hit when the civil war was outbreak and witnessed so many 
miserable actions including endless clan conflicts within the community of the Baidoa Town. Along with that, in September 1995, United Somalia Congress Militia (USC) led by Mohamed Farah Aidid (warlord) has attacked and occupied the territory of Southwest regions particularly Baidoa Town. Followed by USC militia injured and killed many more innocent people live in Baidoa and its near villages and displaced large number of people into other places in Southwest regions and as well as neighbor countries in order to escape their life due to rape, kill and other severe human violations from USC militia controlled by Bay region.

The USC militia remained the control of Baidoa Town until midst of January in 1996. Rahanweyn Resistance Army (RRA) led by Hassan Mohamed Nur (Shati-gadud) exhausted USC militia. Finally, the USC forces has completely removed in the Bay region in June 1996. In 1999, the RRA forces detained control of the entire Bay, Lower Shabelle, Gedo and Bakool regions as they constituted a province by engaged more peace and stability aforementioned southwest regions of Somalia.

At this present in Baidoa, it is quite stable but not fully reliable in terms of political as well as security; although ordinary life business is doing well. Although lack of state protection, insecurity, fighting and conflicts based on inter-clan clashes can still erupt at any time. Frequent humanitarian crises have been happening in the town and the surrounding villages.

\section{During Reewing Resistance Army (RRA) Administration in Baidoa: Reality and Myth}

Broadly speaking, Reewing Resistance Army (RRA) is an autonomist militant group that was operating in Southern regions of Somalia. This militant group mainly established to defend the land and dignity of southwest regions' people and to resist the invading forces of Aidid (USC Militia Leader). To become independent state of southwest regions of Somalia under the leadership of Hassan Mohamed Nur (Shati-gadud) was the key political ambitions by RRA party as the community of Digil \& Mirifle believe that he was great visionary leader. RRA found on 13 October 1995, assembly of traditional elders, religious and intellectuals from majority of Reewing tribes at Jhaffey, west of Baidoa (Hussein. I, personal communication, February 10, 2020).

In fact, RRA militia was built with the idea of tribalism and definitely not a clear vision and strategy developed by top leaders of RRA as a future reference. In addition, Majority of RRA Executive Board were illiterates and they only proposed negative feelings for people coming from outside the group. Although most of the Digil \& Mirifle tribes in southwest regions were invited to support unconditionally and defend, their territory in order to fight with USC forces those has illegally occupied and initially plans to widen entire of southern regions. Where RRA militant group getting support? It is quite difficult to get the correct answer of this question, but it is for sure that local people have fully supported to RRA as they trust to bring peace and political maturity in the whole of the regions. On the other hand, the political analysts from southern regions believe that RRA has been getting support and logistics arrangements from the external group (Yusuf. A, personal communication, February 15, 2020).

It cannot be ignored that RRA militia themselves committed serious abuses including revenge 
killings, powering specific clans by providing illegal weapons, forcibly soldiering children and adults, arbitrary executions and a lot of serious of human rights violations at areas under their controlled. The battle between RRA and USC forces against one another caused in devastation of all infrastructure services, death of hundreds of innocent civilians, huge internal displacement due to exchange of gun fires in the Baidoa town.

\section{Commencement of Inter-Clan Conflict In Baidoa District}

Since from the outbreak of the civil war in 1991, Somalia has experienced a disproportional large number of clan-based conflicts by fought over resources such water, livestock and grazing land (Ali \& Neelam, 2019). However, the clan-based conflict in Baidoa district can be summarize into three categories: the Social inequality, the Economic Decline and The Access of weapons among the civilians (Elmi \& Barise, 2006). As the world sees that Somali people is comparatively homogenous and linguistically (Somali) and religiously (Islam). But in the context of reality, is not like that, clan interest is measured more significant than nationhood, and the picture of Somalia conflict is absolutely responsible by tribalism as it influences all aspects of Somalis life (Shortland e tal, 2013). Hence, due to control of power, resources, political chaos and other rivalries has significantly created clan boundaries in several parts of the region particularly Baidoa district with the formation of new clans uniting their position on occupied lands and caused to forfeit great lives. This is likely that one of the problematic issues expecting from every clan, sub-clans in Somalia likely negative to every modern administration will have to discourse is the impac on changed structure of clan distribution on state and societal relations, which could potentially fuel several forms of conflict (Samatar, 1992).

\section{The Role of Traditional Elders in Conflict Resolution}

The role of traditional elders in managing a conflict in Somalia context was and is, for the most important pillar part. As other African nations, Somalia practices in a state of basic legal system such as customary law (Xeer), religious law (Sharia) and domestic laws are operating (Kariuki \& Kazeem, 2009). Traditional elders in southwest regions of Somalia have been playing a key role in solving most conflicts arise in the basic units of society like within families, clans, villages, and other small units. Elders provide one of the most central frameworks that are in place for the resolution of conflicts and for preventing their escalation into violence, thus threatening the social fabric (Barrow, 2018).

According to Reewing/Digil \& Mirifle Community Elders authority structures chiefly come into three traditional ways for both clan and sub-clan members. First is through Election System whereby clan and sub-clan members choose their representative elder. Second is through Inheritance-when a person and fully respected clan elder passed away and then clan members crown the son of the passed elder and request the son to pertain the responsibilities of his father. Third is through Appointment-this method comes through nomination from the clan council authorities and this is quite least effective of the three in terms of legitimacy power (Conciliation Resources, 2010). Moreover, the Malaaq (clan chief) should possess specific qualities and criteria in his leadership competency including religious man, who has well enough knowledge of practicing Islamic Sharia, honest, impartiality, good 
decision-maker, upright communication skills, and many other abilities to engage with people outside of his own sub-clan (Hansen, 2003).

It is worth to mention that Reewing elders have been frontline to sustain for peace and solved thousands of hundreds of clan fighting and revenge killings in Baidoa district with effective application of customary law. Conflict resolution by elders is basic on cultural values, norms, beliefs with real use of Islamic law.

\section{Materials and Methods}

The purpose of this study was to examine Inter-Clan Conflicts in Somalia: When Peace Happen particularly the study looks Baidoa district. The study was used descriptive research design. The target population of this study was some selected residents in Baidoa. The population size of the study was 103 respondents through utilizing purposive sampling due to security issue; the researcher chooses a specific population based on a unique reason. The study distributed questionnaire and analyzed the collected data by Statistical Package for Social Science (SPSS Version 16.0) software.

\section{Findings and Discusions}

The clan conflict in Somalia in the 1990s was increased by the access of a large quantity of illegal weapons obtained during the Cold War from differ nations in Africa and other regions for the purpose of paralyzing the Somalia government. Clan conflicts was used as a resource to reach power in a vacuum approach. However, when it comes to describe the root cause of inter-clan conflicts in Somalia is certainly from injustice, Siad Barre dictatorship system and several factors contributed to the political crisis: decolonization, the electoral system and the elections of the 1960s, nationalism, and urbanization. These factors provided the conditions for interclan antagonism, the politics of factionalism, a military coup and the interclan battles that led to the dissolution of the State (Ingiriis, 2018).

\section{Demographic Characteristics of the Respondents}

The Basic demographic characteristics of the study population are gender, age, marital status, and as well as educational level of the participant.

As Gender, the most respondents of the study were male 86 respondents (83\%) while 17 respondents were female (17\%). In terms age, most of the respondents of this study were aged between 25-35 years, 79 respondents (77\%), aged between 35-45 years which are 14 respondents $(13 \%)$, the respondents aged between less than 25 years were 7 respondents (7\%), and respondents aged between 50 -above years were 3 respondents $(3 \%)$. In considering, marital status, the majority of the respondents were married 89, (86\%), 10 respondents were never married (10\%), while 4 respondents were divorce/window, (4\%). Regarding education level, the majority of the respondents of this research were master level, 79 respondents (77\%), Bachelor level 21 respondents (20\%) and Ph.D. degrees were 3 respondents (3\%) and there are no secondary/Diploma level holders in this study. 


\section{Data Interpretation and Analysis}

In this section summarizes the means and standard deviations of the all attempted questions respective with the study objectives in the distributed questionnaire. Objective (1) of the study was to investigate the impact of community illiteracy on peace. 15 questions were asked to the respondents about how high rate of community illiteracy can drive to remain frequent inter-clan fighting in Baidoa district, as the whole country has been nationless since after the collapsed of central government of Somalia in 1991 onwards weak institutions. Concerning to the result, most clan conflicts in Baidoa district is endorsing by clan militia, which is resulting violation of humankind, as the mean index (4.3) and standard deviation (0.88) shows strongly, agree level. Objective (2) of the study was to examine the absence of Rule of Law on peace stability. In this objective, 10 questions were asked to the study respondents. Result from the respondents' shows that absence of Rule of Law is the biggest problem entire of southwest regions of Somalia particularly Baidoa district as resulted to be remain frequent clan conflicts everywhere in the region. The mean index (3.94) and standard deviation (1.67) indicates agree level. Objective (3) of the study was to explore clan illegal weapon (access of weapons) on peace. 5 questions were distributed to the respondents and their responses shows that clan access of weapons has absolutely encourage repeated clan and sub-clans fighting in city as it lost hundreds of Somalis lives, leading to massive internal displacement and refuges all over the world escaping from the wars zone seeking better and peaceful lives elsewhere. The mean index or the averages means of these indicators and standard deviations are (3.44) and (0.98) respectively, the mean index and standard deviation indicates Agree.

\section{Conclusion and Recommendation}

The purpose of this study was to examine Inter-Clan Conflicts in Somalia: When Peace Happen with special reference to Baidoa district. The findings indicates that land ownership dispute, pastures, water, and political-economic and other resources mostly cause the major drivers of the conflict between the tribes in Baidoa district. Furthermore, the results also revealed that uncontrollable urbanization including internal displaced people have been increased frequent inter-clan conflicts due to occupying illegal settlements without getting any permission by the landowner. It was also indicated that lack of rule of law in Baidoa district, inter-clan conflicts is the biggest problem that not yet settled to overcome because of each tribe has access of weapons. The findings of the study will be significant, as it will help inform policy interventions, security sector, traditional elders, peace activists and other actors in addressing inter-clan conflicts generally and specifically those in marginalized areas of Baidoa district in particular. It worth to mention that traditional elders of each clan and sub-clans in Baidoa district have been playing a crucial role in reducing inter-clan conflicts, revenge killings and other human rights violations.

\section{Recommendations}

Based on the study findings, the study would like to recommend several points related to inter-clan conflicts solutions in Baidoa district. 
I. To disarm the militias of each clan and return their weapons in to the State Administration

II. To establish and pass Rule of Law Acting

III. Call for reconciliation and peace-building conferences

IV. To propose security strategic at state level

V. Community Awareness on domestic crimes, peace and unity

VI. To build police stations with qualified police forces of each village in Baidoa district

\section{Reference}

Adam, H. (2007). Somalia: militarism, warlordism or democracy?. Journal Review of African Political Economy, 19(54). https://doi.org/10.1080/03056249208703950

Ahad, A. M. (2014). The externally defined Somali national identity. Journal of Somali Studies, 1(1), $35-61$.

Ali, A. A., \& Pandey, N. (2019). Understanding the concept of Grassroots peace-building process: A study. Adalya Journal, 8(9).

Ali, Y. S. A. etal. (2019). Federalism in post-conflict states: Assessing Somalia's challenges and the way forward. Perspectives on Federalism, 11(2).

Ayelen, F. (2017). Somalia's turbulent path to peace and stability. International Journal of Peace and Development Studies, 8(4), 47-54. https://doi.org/10.5897/IJPDS2017.0301

Barrow, I. H. (2019). Internal Security Crisis in Somalia: Lesson From The Civil War in 1990. Asian Journal of Management Sciences \& Education, 8(2).

Cheeseman etal. (2018). War and democracy: the legacy of conflict in East Africa. The Journal of Modern African Studies, 56(1), 31-61. https://doi.org/10.1017/S0022278X17000623

Conciliation Resources. (2010). Whose peace is it anyway? Connecting Somali and international peacemaking. http://www.c-r.org/accord/somalia/building-peace-south-central-somalia-role-elders

Elmi, A. (2014). Decentralization Options for Somalia. The Heritage Institute for Policy Studies. www.heritageinstitute.org.

Elmi, A. A., \& Barise, A. (2006). The Somali Conflict: Root causes, obstacles, and peace-building strategies. African Security Review 15(1). https://doi.org/10.1080/10246029.2006.9627386

Hammond, L. (2013). Somalia rising: things are starting to change for the world's longest failed state. Journal of Eastern African Studies, 7(1). https://doi.org/10.1080/17531055.2012.755316 
Hansen, S. J. (2003). Warlords and Peace Strategies: The Case of Somalia. The Journal of Conflict Studies,

Hassan, M. (2018, December 19). Somali Region Gets New President After Deadly Election Campaign.

VOA.

https://www.voanews.com/africa/somali-region-gets-new-president-after-deadly-election-cam paign.

Healy, S., \& Bradbury, M. (2010). Endless War: a brief history of the Somalia conflict. Accord an international review of peace initiatives, (21).

Ibrahim, H., (2018). The Role of the Traditional Somali Model in Peacemaking. The Journal of Social Encounters, 2(1), 60-68.

Ingiriis, M. H. (2018). State and Clan Violence in Somalia. African Conflict and Peacebuilding Review, 8(1). https://doi.org/10.2979/africonfpeacrevi.8.1.04

Ingiriis, M. H. (2018). Building peace from the margins in Somalia: The case for political settlement with Al-Shabaab. Journal Contemporary Security Policy, 39(4). https://doi.org/10.1080/13523260.2018.1429751

Kariuki, F., \& Kazeem, F. A. (2009). Conflict Resolution by Elders in Africa: Successes, Challenges and Opportunities. Journal of Law and Conflict Resolution, 1(3), 060-067.

Kirschner, S., \& Miller, A. (2019). Does Peacekeeping Really Bring Peace? Peacekeepers and Combatant-perpetrated Sexual Violence in Civil Wars. Journal of Conflict Resolution, 64(9). https://doi.org/10.1177/0022002719831069

Kusow, A. M. (2012). The Genesis of the Somali Civil War: A New Perspective. Northeast African Studies, Volume 1, Number 1, (New Series) 1994, pp. 31-46. Human Rights Watch (2018). Somalia Events of 2017. https://doi.org/10.1353/nas.1994.0004

Makhubela. (2016, August 16). Understanding Civil Militia Groups in Somalia. African Centre for the Constructive Resolution of Disputes. https://www.accord.org.za/conflict-trends/understanding-civil-militia-groups-somalia/

Makinda, S. (2007). Politics and clan rivalry in Somalia. Journal Australian Journal of Political Science, 26(1). https://doi.org/10.1080/00323269108402139

Manipulated electoral process escalates inter-clan conflict. (2017, January 4). https://reliefweb.int/report/somalia/manipulated-electoral-process-escalates-inter-clan-conflic $\mathrm{t}$

Mueller, C. J. (2016). The Evolution of Political Violence: The Case of Somalia's Al-Shabaab. $\begin{array}{llll}\text { Journal Terrorism and } & \text { Political }\end{array}$ https://doi.org/10.1080/09546553.2016.1165213

Muse, H. A. (2019). The Political Crisis in Somalia and the Clan System: A

Samatar, A. I. (1992). Destruction of State and Society in Somalia: Beyond the Tribal 


\section{Macrothink}

International Journal of Human Resource Studies

ISSN 2162-3058 2020, Vol. 10, No. 4

Convention. The Journal of Modern African Studies, 30(4).

Scholarly and Creative Works for Minnesota State University, Mankato. https://cornerstone.lib.mnsu.edu/etds/941/

Shortland, A., Christopoulou, K., \& Makatsoris, C. (2013). War and famine, peace and light? The economic dynamics of conflict in Somalia 1993-2009. Journal of Peace Research, 50(5) 545-561. https://doi.org/10.1177/0022343313492991

Sociological Review of News Media Analyses [Master's thesis, Minnesota State University, Mankato]. Cornerstone: A Collection of

Stremlau, N. (2019). Governance without Government in the Somali Territories. Journal of International Affairs.

Yusuf, A, M., \& Lewa, E., (2019). Challenges of Implementing Federal Governance in Somalia. International Journals of Academics \& Research, 1. https://doi.org/10.32898/ihssj.02/1.4article07

\section{Copyright Disclaimer}

Copyright for this article is retained by the author(s), with first publication rights granted to the journal.

This is an open-access article distributed under the terms and conditions of the Creative Commons Attribution license (http://creativecommons.org/licenses/by/4.0/). 